\title{
ZERO TOLERANCE
}

\section{Dear Reader,}

Alcohol is your rescuer in times of need, sang the German rock musician Herbert Grönemeyer back in 1984, commenting on the drink problems of many Germans. And the subject is no less relevant today. There are still far too many deaths on our roads caused by drink-driving.

A sensible way of reducing the number of people being killed or injured would be to introduce a $0.0 \mathrm{mg}$ per $\mathrm{ml}$ bloodalcohol limit, as is customary in other European countries (Estonia, Romania, Slovakia, Czech Republic and Hungary). The majority of Germans would be in favour: according to a study by the insurance company DA Direkt, two out of every three people questioned supported an absolute ban on alcohol in road traffic.

Zero means zero, one might say - a clear rule for everyone, which should finally put an end to comments like "the odd pint or two won't do any harm, surely”. Just how easy it is to underestimate the effects of "the odd pint or two" was shown some time ago when the Bavarian prime minister, Günther Beckstein, erroneously claimed that a "real man" would still be able to drive a car after downing a couple of litre-sized glasses of good Bavarian beer.

Drink-driving is not a trivial offence. Last year, according to the ACE Auto Club, approximately 58,000 people were killed in accidents on German roads and around 7100 of these, or 12 percent, were alcohol-related.

But it is doubtful whether the government's new penalty points system will solve the problem. Germany's Federal Transport Minister, Peter Ramsauer, is planning a radical reform. Instead of the previous system, which imposed between 1 and 7 points depending on the seriousness of the offence, there are to be only two categories, 1 and 2, for offences in the future. France is taking a different approach, but one that has met with an incredulous shake of the head by most people. From 1 July, every driver will be required by law to carry an unused and fully functional breathalyser kit in the car. As if simply carrying a breathalyser will make people drink less. And what is more: the legal obligation also applies to holidaymakers. A better idea came from Sweden. As long ago as 2010, Volvo launched Alcoguard, a breathalyser system that is completely integrated into the vehicle. If the bloodalcohol limit is exceeded, the engine will not start.

To support zero tolerance, I believe that more intensive police checks are just as important. But that would cost taxpayers more money for personnel and equipment - money that, at the moment, tends to be invested more lucratively in parking wardens. In the long term, there is no alternative to $0.0 \mathrm{mg} / \mathrm{ml}$. Or simply: If you drink, don't drive.

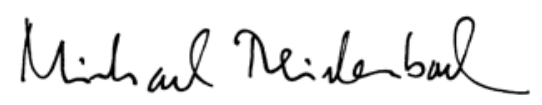

DIPL.-ING. MICHAEL REICHENBACH,

Vice-Editor in Chief

Wiesbaden, 28 March 2012

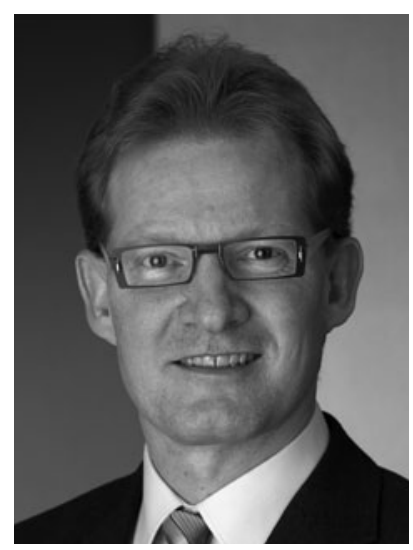

